\title{
Correction: Spore development and nuclear inheritance in arbuscular mycorrhizal fungi
}

\author{
Julie Marleau', Yolande Dalpé ${ }^{1,2}$, Marc St-Arnaud ${ }^{1}$ and Mohamed Hijri ${ }^{*}$
}

\section{Correction}

After the publication of this work [1], we found that the equations of linear regressions in the section "Live cell imaging of AMF spores" didn't correspond to those shown in figure two (Figure 1 in this article) which was due to an inversion of the axis during the revision. Figure two shows regressions of the spore diameter $(y)$ plotted against the number of nuclei in juvenile and mature spores $(\mathrm{x})$, while in the text we showed equations of linear regressions of the number of nuclei (y) plotted against the spore
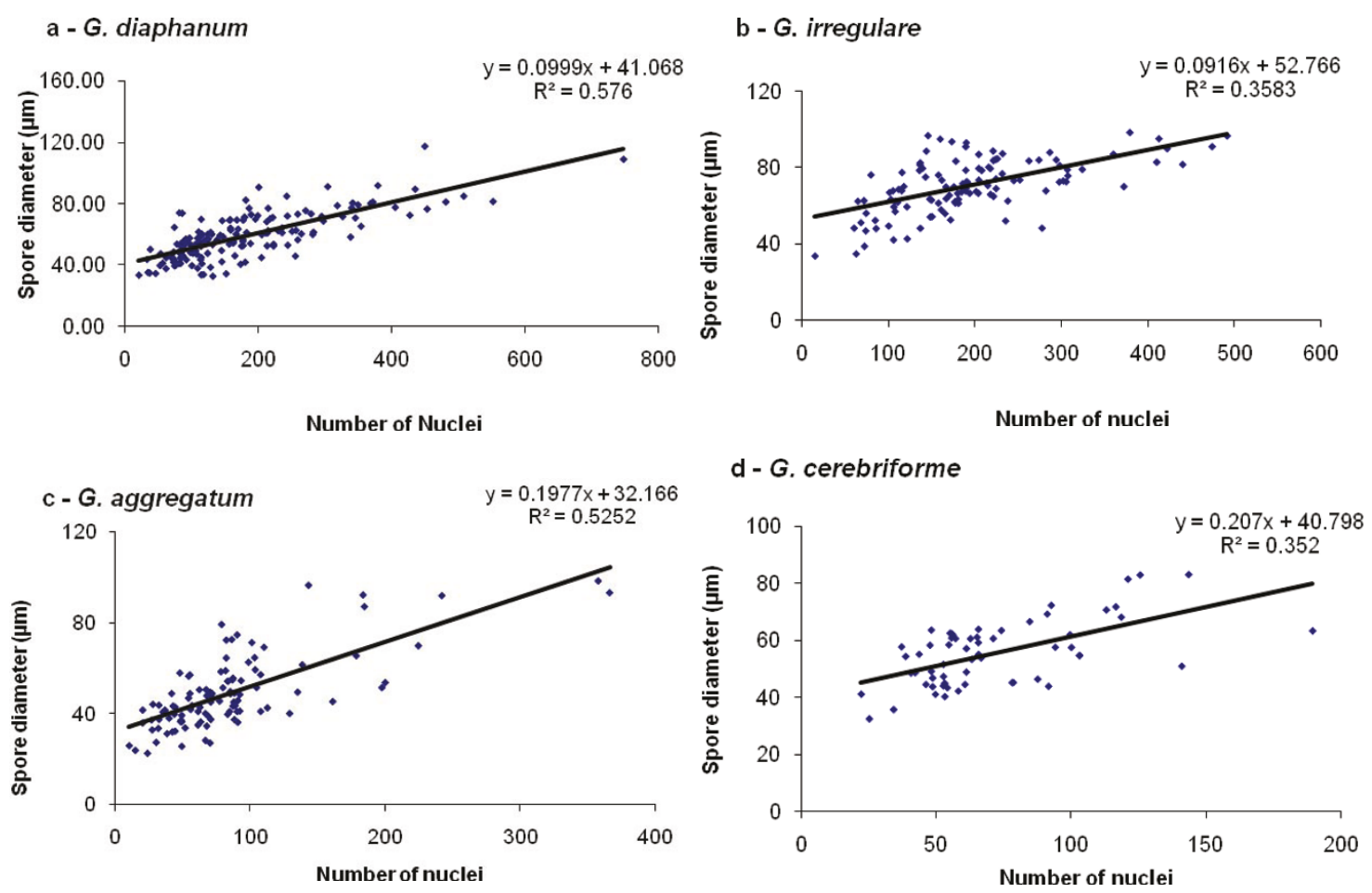

Figure 1 Figure two: Number of nuclei per spore. The spore diameter of juvenile and mature spores (y) plotted against the number of nuclei in spore (x). G. cerebriforme spores had the smallest number of nuclei per spore and were also the smallest in size, while G. diaphanum spores had the largest number of nuclei per spore. There is a positive linear relation between the number of nuclei per spore and spore diameter: $\mathbf{A}, G$. diaphanum ( $\left.y=0.0999 x+41.068, R^{2}=0.576\right) ; B$, G. irregulare $\left(y=0.0916 x+52.766, R^{2}=0.358\right) ; C, G$ aggregatum $\left(y=0.1977 x+32.166, R^{2}=\right.$ 0.525); and $\mathbf{D}$, G. cerebriforme $\left(y=0.207 x+40.798, R^{2}=0.352\right)$. All slopes were statistically significant at $p<0.05$.

\footnotetext{
* Correspondence: Mohamed.Hijri@umontreal.ca

'Université de Montréal, Département de sciences biologiques, Institut de recherche en biologie végétale, 4101 rue Sherbrooke Est, QC, H1X 2B2,

Canada

Full list of author information is available at the end of the article
}

\section{() Biomed Central}

(c) 2011 Marleau et al; licensee BioMed Central Ltd. This is an Open Access article distributed under the terms of the Creative Commons Attribution License (http://creativecommons.org/licenses/by/2.0), which permits unrestricted use, distribution, and reproduction in any medium, provided the original work is properly cited. 
diameter ( $\mathrm{x}$ ) for each AMF species. The inversion of the axis didn't affect our conclusions.

We would like to correct equations of these linear regressions in the text in page 3 as follow:

We found a positive linear relation between the number of nuclei in a given spore and its diameter for all AMF taxa: Glomus diaphanum $(\mathrm{y}=0.0999 \mathrm{x}+41.068$, $\left.\mathrm{R}^{2}=0.576\right)$, Glomus irregulare $(\mathrm{y}=0.0916 \mathrm{x}+52.766$, $\left.\mathrm{R}^{2}=0.358\right)$, Glomus aggregatum $(\mathrm{y}=0.1977 \mathrm{x}+32.166$, $\left.\mathrm{R}^{2}=0.525\right)$ and Glomus cerebriforme $(\mathrm{y}=0.207 \mathrm{x}+$ $40.798, R^{2}=0.352$ ). All slopes were statistically significant at $p=0.05$.

We apologise for any inconvenience that this inaccuracy in presentation of the data used in the article [1] might have caused.

\section{Author details}

${ }^{1}$ Université de Montréal, Département de sciences biologiques, Institut de recherche en biologie végétale, 4101 rue Sherbrooke Est, QC, H1X 2B2, Canada. ${ }^{2}$ Agriculture and Agri-Food Canada, 960 Carling Ave. Ottawa, On, K1A 0C6, Canada.

Received: 5 April 2011 Accepted: 14 April 2011 Published: 14 April 2011

\section{Reference}

1. Marleau J, Dalpé Y, St-Arnaud M, Hijri M: Spore development and nuclear inheritance in arbuscular mycorrhizal fungi. BMC Evolutionary Biology 2011, 11:51.

doi:10.1186/1471-2148-11-97

Cite this article as: Marleau et al:: Correction: Spore development and nuclear inheritance in arbuscular mycorrhizal fungi. BMC Evolutionary Biology 2011 11:97.

\section{Submit your next manuscript to BioMed Central} and take full advantage of:

- Convenient online submission

- Thorough peer review

- No space constraints or color figure charges

- Immediate publication on acceptance

- Inclusion in PubMed, CAS, Scopus and Google Scholar

- Research which is freely available for redistribution

Submit your manuscript at www.biomedcentral.com/submit 